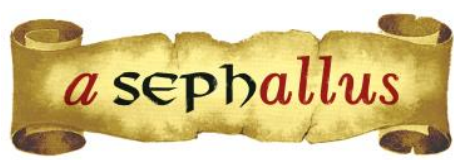

Revista aSEPHallus de Orientação Lacaniana

Núcleo Sephora de Pesquisa sobre o Moderno e o Contemporâneo

ISSN 1809 - 709 X

\title{
Da estrutura autista ${ }^{1}$
}

Jean-Claude Maleval

Psicanalista Membro da École de la Cause Freudienne e da Associação Mundial de Psicanálise (Paris, França) Professor emérito de Psicologia Clínica na Universidade de Rennes 2 (Paris, França)

E-mai: jean-claude.maleval@univ-rennes2.fr

\begin{abstract}
Resumo: A noção de estrutura subjetiva autística foi introduzida por Rosine e Robert Lefort nos anos 1990 e caracterizada pela ausência de alienação significante, de lalíngua, de S1 e de objeto a. Estas indicações são ainda objeto de debate atualmente pois, para apreender a complexidade da clínica do espectro autista, estes autores só dispunham da noção de divisão do sujeito no real do duplo. A extração mais precisa da estrutura autística requer alguns passos suplementares a partir de elementos que eles não dispunham: novos documentos clínicos, estudos sobre a cognição dos autistas e a formação do conceito de borda. Hoje em dia parece possível apreender a estrutura autista a partir de características maiores, tais como: uma retenção inicial dos objetos pulsionais; uma alienação retida, que se opera sem a dobradiça do significante-mestre; uma aparelhagem do gozo pela borda.
\end{abstract}

Palavras-chave: psicanálise; autismo; estrutura; autista de alto nível; Asperger; signo.

De la structure autistique : La notion de structure subjective autistique a été introduite par Rosine et Robert Lefort dans les années 1990 et caractérisée par l'absence d'aliénation significative, de lalanguage, de $\mathrm{S} 1$ et d'objet a. Ces indications sont encore en discussion de nos jours car, pour comprendre la complexité de la clinique du spectre autistique, ces auteurs n'ont eu l'idée que de diviser le sujet en réel du double. L'extraction plus précise de la structure autistique nécessite des étapes supplémentaires à partir d'éléments qu'ils ne possédaient pas: nouveaux documents cliniques, études sur la cognition de l'autiste et formation du concept de bord. De nos jours, il semble possible d'appréhender la structure autistique à partir d'éléments plus vastes, tels que: une rétention initiale des objets pulsionnels; une aliénation conservée, qui fonctionne sans la charnière du maître-signifiant; un appareil de jouissance par le bord.

Mots-clés: psychanalyse; l'autisme; la structure; autiste de haut niveau; Asperger; signe.

On autistic structure: The notion of autistic subjective structure was introduced by Rosine and Robert Lefort in the 1990s and characterized by the absence of significant alienation, from lalangue, from S1 and from object a. These indications are still under discussion today because, in order to understand the complexity of the autistic spectrum clinic, these authors only had the notion of dividing the subject into the real of the double. The more precise extraction of the autistic structure requires some additional steps from elements that they did not have: new clinical documents, studies on the cognition of the autistic and the formation of the concept of edge. Nowadays it seems possible to apprehend the autistic structure from larger features, such as: an initial retention of the pulsional objects; a retained alienation, which operates without the hinge of the master-signifier; an apparatus of enjoyment by the edge.

Keywords: psychoanalysis; autism; structure; high-level autistic; Asperger; sign. 


\section{Da estrutura autista}

Jean-Claude Maleval

A noção de estrutura subjetiva autística foi introduzida por Rosine e Robert Lefort nos anos 1990. Os autores tentaram extrair certas características principais, a partir da cura de MarieFrançoise, relatada em 1980 em "Nascimento do Outro" (Lefort \& Lefort, 1980) acentuando a ausência de alienação significante, de lalíngua, de S1 e de objeto $a$. Entretanto, estas indicações são hoje ainda objeto de debate, uma vez que para apreender a complexidade da clínica do espectro autista, só dispunham naquela época da noção de divisão do sujeito no real do duplo. A exploração desta hipótese em "A distinção do autismo" (Lefort \& Lefort, 2003), em 2003, não traz uma contribuição decisiva para a clínica dos autistas de alto nível. Para extrair mais precisamente a estrutura autística, alguns passos suplementares parecem necessários. Elementos dos quais eles não dispunham podem contribuir: novos documentos clínicos, estudos sobre a cognição dos autistas e a formação do conceito de borda.

Hoje em dia parece possível apreender a estrutura autista a partir de três características maiores.

- Uma retenção inicial dos objetos pulsionais

- Uma alienação retida, que se opera sem a dobradiça do significante-mestre.

- Uma aparelhagem do gozo pela borda.

A hipótese da existência de uma estrutura autística abriga a noção de espectro do autismo introduzida em 2013 pelo DSM-5 para substituir os "transtornos invasivos do desenvolvimento". Haveria fundamento em postular possibilidades de passagem das formas mais severas do autismo kanneriano à socialização dos autistas de alto nível? O destino de Donald Gay Tripplet, o caso n ${ }^{0} 1$ do artigo "Princeps" de Kanner, é o mais demonstrativo e o menos contestável destas possíveis evoluções. Observado nos anos 1930 no hospital Johns Hopkins de Baltimore, em 2010 ele gozava de uma pacífica aposentadoria no Mississipi. Após ter trabalhado como caixa no banco de seus pais, ele vivia independente e sozinho, ainda dirigia seu carro e continuava a cultivar seus lazeres: o golfe e as viagens (Dovan \& Zucker, 2010). Aos três anos de idade, Grandin era uma criança muda, colérica, fixada em objetos que giravam, procurando estar sempre sozinha e brincando com seus excrementos. Ela considera, como muitos especialistas, que a severidade dos sintomas em torno dos dois ou três anos é frequentemente sem relação com o prognóstico (Grandin, 1997).

\section{Uma retenção inicial dos objetos pulsionais}

Hoje em dia é quase consenso que os dois sinais mais precoces do autismo podem ser percebidos muito cedo; o primeiro, a fuga do olhar em torno dos três meses e o segundo, a falta de atenção compartilhada, em torno dos nove meses. Isto significa que quando a criança aponta 
para um objeto, ela não utiliza seu olhar para atrair a atenção do adulto para o alvo de seu interesse. Esses dois sinais são de uma mesma ordem: a criança autista não utiliza o olhar para se comunicar. Não se trata de uma anedota: o fenômeno persiste na maior parte dos autistas de alto nível. Porém, não são só as interações escópicas que o pequeno autista evita: todos os objetos mobilizados nas primeiras trocas com os pais, a voz, as fezes e o alimento, são, em maior ou menor escala, recusados ou retidos.

Kanner percebe logo de início que há uma recusa precoce dos alimentos. A retenção do objeto anal é tão frequente quanto a do olhar e a da voz. É necessária muitas vezes a realização de lavagens para evitar a oclusão intestinal. Uma proporção importante de autistas permanece muda durante seus primeiros anos, numa recusa em ceder suas vozes às expectativas do Outro. Alguns experimentam esta recusa como uma força que ultrapassa sua vontade, já outros parecem se reprimir por prudência. "Por que não falamos normalmente?" Questiona Higashida sobre seu computador. "Eu não sei. Não é que não queremos, é que não podemos, e sofremos com isso" (Higashida, 2014, p.46).

Às vezes Sellin pronuncia algumas palavras, mas ele não é capaz de explicitar as motivações de seu mutismo:

... às vezes eu digo uma coisa de repente

aí fico muito surpreso comigo mesmo de isso ter acontecido

Não tenho como dar explicação

Acho simplesmente que deve ser uma prova de que

a faculdade de falar existe

resta encontrar um meio de sair do mutismo (Sellin, 1998, p.25).

Alguns autistas podem testemunhar que a liberação da voz é vivida como uma angustiante perda de substância que equivaleria a uma mutilação: Bettelheim nos relata, que "diversas crianças anteriormente mudas, posteriormente nos dirão que não falavam por que isto esvaziaria seu cérebro" (Bettelheim, 1969, p.89).

Por que a reter o olhar? Por que, segundo um deles, é muito inquietante. Por que tentar evitar a defecação? Por medo, um outro nos conta, de que os pulmões explodam. Por que o mutismo? Por receio, segundo alguns, de esvaziar o cérebro.

Todos estes fenômenos sugerem fortemente que o autismo se enraíza muito cedo em uma angústia em interagir com os outros, que não é da ordem da incompreensão das relações sociais, mas de uma angústia irracional que o sujeito não domina. A criança autista recusa inicialmente trazer os objetos pulsionais para a troca; é a conclusão de Donna Williams, ressaltando que em sua infância, tudo o que girava "em torno do ato de dar e receber the era perfeitamente estranho" (Williams, 1992, p.66). 
$\mathrm{Na}$ fonte do autismo se encontra uma retenção dos objetos pulsionais, que suscita uma perturbação da comunicação, pois sua cessão está no fundamento da entrada na relação com o Outro. Os primeiros gritos do autista são monocórdicos, sem modulações, em bebês surpreendentemente calmos, ou então são frequentes gritarias que nada consegue parar. Nos dois casos, os pais não são colocados na posição de interpretá-los como demandas.

\section{Uma alienação sem o entroncamento do significante mestre}

A recusa de inserir a voz na troca gera duas condutas frequentes no autista: o mutismo quando uma resposta the é exigida e tapar as orelhas quando Ihe falam. Como adquirir a linguagem nestas condições? O autista parece recorrer a duas condutas bem diferentes que têm em comum evitarem o uso da voz. Mottron acentua este ponto: "as crianças autistas", segundo ele, "aprendem a linguagem sem passar por dois de seus componentes mais importantes na pessoa típica, quais sejam, a interação social e a significação" (Mottron, 2016, p.188). Existem dois canais maiores de entrada na linguagem pelo autista; um, passa pelos balbucios pobres e a ecolalia; o outro, principalmente pela escrita. Nos dois casos, o sujeito busca evitar a interação social. O primeiro canal desconsidera a significação; o segundo exclui o gozo vocal. Disto resulta uma cisão chocante entre dois modos de expressão.

Frequentemente, quando falam, segundo um clínico, os autistas o fazem com uma voz átona, mecânica, como se [...] a parte musical da língua estivesse dissociada do sentido, como se eles tivessem a escolha entre falar sem musicalidade ou produzir sons sem sentido: tem-se o sentido bruto ou o som bruto, código informativo ou emoção sensível, mas nunca os dois articulados (Hébert, 2006, p.208).

O som bruto, oriundo do balbucio e das ecolalias, portador de emoções sensíveis, não comunicáveis, se desdobra em uma língua verbosa, própria às satisfações vocais solitárias; enquanto a aquisição da linguagem pela escrita favorece a emergência de um "sentido bruto", de um "código informativo", de uma língua factual apta à comunicação, mas desprovida de afetos.

\section{O balbucio autístico}

Desde a década de 70 , os psicólogos contataram que as condutas de evitação são encontradas muito cedo no bebê que virá a se tornar autista, a fuga do olhar e a ausência de apontamento proto-declarativo aparecem com frequência desde o primeiro ano de idade. Estamos de acordo em considerar que estes bebês não buscam a reciprocidade que "se organiza em torno da troca de olhares, de vocalizações das trocas de papéis entre a mãe e a criança" (Richer, 1978, p.69). Durante os primeiros meses, certas crianças autistas não balbuciam, mas choram ou gritam quando estão acordados. Outros ficam em silêncio. Quando o balbucio existe, ele aparece 
frequentemente de forma monótona (comparável à de um bebê caindo de sono), sem ânimo, sem inflexão intencional. Além disso, ele não se adapta às produções da mãe. Há autistas que só balbuciam quando estão sozinhos, na presença de algum parente ficam em silêncio.

Os mais recentes estudos sobre os balbucios e vocalizações do bebê autista ressaltam que suas características principais residem em uma pobreza estatisticamente significativa e de uma mínima busca de trocas interativas. De zero a seis meses, a frequência das vocalizações entre bebês que se tornarão autistas e os outros se mostra equivalente; entretanto, a partir dos seis meses, período da aparição do balbucio, a diferença aparece com clareza (Chericoni et al, 2016). Quando o balbucio está presente, os estudos constatam a atipicidade da forma de sua manifestação: além de sua pouca frequência, ele é pouco coordenado com o olhar, mais solitário do que interativo, parecendo menos socialmente orientado.

Este ponto é essencial porque os elementos do balbucio só podem adquirir significação a partir da resposta do Outro. A entrada na linguagem, ressalta Lacan, se opera a favor da transformação do grito em apelo. Para que o sujeito se torne invocante, uma cessão do objeto voz é necessária, é preciso que o sujeito aceite fazer "ressoar seu grito" no vazio do Outro, o que torna possível "encontrar as marcas de respostas que foram aptas a transformar seu grito em apelo". Quando Lacan escreve estas linhas em 1960, ele ainda não havia cunhado a noção de S1, mas ele já designa como "insígnias as marcas onde se inscrevem o todo-poder da resposta" (Lacan, 1966, p.679). Indica assim, que a entrada na linguagem se faz para o infante, por meio da escolha dentre os significantes propostos como resposta a seu grito, daquele que vai se tornar um S1 próprio a converter o grito em chamado. Se é bem assim, e o significante da resposta do Outro deve ser previamente ouvido para que o grito desapareça diante do S1 de apelo, então a alienação no discurso do Outro deveria ser discernível desde o balbucio. É exatamente isso que sustentam atualmente os linguistas contemporâneos que não o reduzem mais a vocalizações sem sentido. Foi constatado que se trata de uma protolinguagem que precede à entrada na linguagem. Segundo eles, o balbucio não é uma linguagem propriamente dita, mas é uma codificação que fornece um quadro para o desenvolvimento da fala (Boysson-Bardies, 1996, p.60), de tal maneira que não existe descontinuidade entre as formas de balbucio e as das primeiras palavras: "Algumas crianças dão assim a impressão de escolher suas primeiras palavras dentre os sons balbuciados que gostavam de produzir" (Lefort \& Lefort, 2003, p.166). É coerente a este respeito que a pobreza do balbucio do autista se prolonga através de primeiras palavras menos numerosas e menos dirigidas (Chericoni et al, 2016, p.8). Por muito tempo acreditamos que o balbucio era apenas um caos desestruturado; entretanto ficou verificado que a partir do oitavo mês, ele revela uma adaptação precoce aos princípios estruturais da língua materna. O balbucio de uma criança inglesa pode ser diferenciado do de um pequeno francês, de um sueco, de um argelino ou de um japonês, ficando demonstrada uma ancoragem precoce do sujeito e de sua enunciação no discurso do Outro.

Foi possível demonstrar que a criança típica "acompanha com vocalizações particulares as 
demandas e as manipulações de objetos como guardar cubos ou de gestos como sentar-se" (Blake \& Boysson-Bardies, 1992) fazendo com que o balbucio possa servir para expressar desejos, interesses e recusas. Ele não é "autista" no sentido de "alheio à comunicação", tanto assim é que o adulto pode utilizá-la para provocar respostas da parte dos bebês. Os Lefort formulam a hipótese de que haveria uma ausência de balbucio na criança autista para sustentar que ela não entra na linguagem passando pelo "balbucio de lalíngua" (Lefort \& Lefort, 1998, p.315), portanto não haveria para ele nem S1 e nem lalíngua. Contudo, os estudos mais recentes evidenciam que a característica maior do balbucio autístico não é sua ausência, mas sua pobreza estatisticamente significativa e sua pouca orientação social, o que induziria a formular a hipótese de uma "lalíngua pobre".

A aproximação entre o balbucio e a lalíngua é feita pelo próprio Lacan, quando informa ter escolhido o termo de forma a que ele ficasse "o mais próximo possível da palavra lalação" (Lacan, 1974). Sinônimo de balbucio e lambdacismo, estes termos designam uma etapa do desenvolvimento da linguagem, que aparece em torno dos seis meses com as primeiras vocalizações e declina progressivamente a partir dos doze meses com a aparição das primeiras palavras. A lalíngua, pura bateria significante, sem gramática, constituída de S1, fundada nas homofonias infantis, enraíza-se no balbucio. Ela constitui a via pela qual se opera uma incorporação do significante: "Lalíngua", afirma Lacan, "aos olhos do gozo fálico é só uma parcela de gozo. É assim que ela se expande para tão além do corpo" (Lacan, 1974). Desde então, é pelo seu intermédio que ocorre a animação do gozo do corpo; "enquanto ela é solidária da realidade dos sentimentos que ela significa" (Lacan, 1974). "Mas existe um encontro entre a lalíngua e o corpo", especifica J.-A. Miller, "e deste encontro nascem marcas que são marcas no corpo. Lacan chama de sintoma a consistência de tais marcas". É assim que o sintoma pode ser reduzido a um mero evento de corpo, algo que aconteceu ao corpo pela ação da lalíngua" (Miller, 2005, p.152). Por outro lado, ela permite ao sujeito apreender modificações corporais sob a forma de afetos conscientes: que são, destaca Lacan, "o que resulta da presença de lalíngua enquanto, de saber, ela articula coisas que vão muito mais longe do que o que o ser falante suporta saber que está sendo enunciado" (Lacan, 1975b, p.127).

Devido ao fato de o grito não ter se transformado em apelo, o autista recebe os significantes de maneira passiva e não interativa, de forma que não têm a capacidade de fazer sentido articulando-se a outros significantes $\mathrm{A}$ especificidade da lalíngua autista é que dela não emergem significantes-mestres. Ela não se presta às articulações que produzem a animação do gozo do corpo. Convém então precisar, como muitas vezes foi observado pelos Lefort, "não é só o S1 que falta no autismo, mas sim todo o tronco do significante mestre inicial, o S1, está foracluído" (Lefort \& Lefort, 1998, p.26). No primeiro plano da clínica do autismo infantil, por intermédio da língua infantil verbosa e das vocalizações involuntárias, vem uma lalíngua que não se apaga, por não se articular ao discurso do Outro. Ela é constituída de vários S1 sozinhos, justapostos. Estão a 
serviço de satisfações solitárias, não da comunicação. A lalíngua autista é pobre porque seus S1 não têm potencial para tornarem-se significantes-mestres que podem marcar o corpo de uma letra no princípio de um sinthoma.

\section{As vocalizações involuntárias}

Em 1946, após observar vinte e três crianças autistas, Kanner constata um fenômeno estranho sobre o mutismo de oito entre eles: "em raras ocasiões ele é interrompido pela emissão de uma frase integral em situações de urgência" (Kanner, 2002).

$\mathrm{O}$ que eles costumam dizer nestes momentos? A primeira frase pronunciada por Birger Sellin é: "devolva minha bola" dirigida a seu pai que acabava de tomar-lhe um de seus objetos autísticos (Sellin, 1994, p.24). Um menino de cinco anos, relata Berquez, que ninguém nunca tinha ouvido falar uma palavra na vida, sentiu-se incomodado quando uma pele de ameixa colouse ao seu palato. Exclamou então distintamente: "Tirem isso de mim", e voltou ao mutismo anterior. Uma outra criança, muda, de quatro anos, durante o exame pelo pediatra gritou: "Quero voltar" e um ano mais tarde, hospitalizado por causa de uma bronquite, ele exclamou: "Eu quero voltar" (Berquez, 1983, p.107).

Todas estas frases possuem um ponto em comum: a presença do sujeito da enunciação está nitidamente marcada. A vocalização involuntária não é uma laboriosa construção intelectual, mas uma palavra que sai das entranhas. Seu caráter imperativo dá testemunho do gozo vocal que o mobiliza. Contudo, a experiência se mostra devastadora para a criança autista, especialmente quando o enunciado é direcionado. É só no ápice da angústia que ele consegue deixar escapar uma vocalização como esta. Ela é vivida como uma mutilação, pois coloca em jogo não somente a alteridade, mas também uma cessão do objeto gozo vocal. Longe de repetir a experiência angustiante, o sujeito procura se proteger de uma repetição murando-se em um silêncio ainda mais profundo.

A enunciação inesperada só surge em situações inquietantes, que apresentem uma característica de necessidade ou de urgência. Nestas circunstâncias, ela não é uma escolha subjetiva refletida e assumida, é uma forma de reflexo suscitada pelo contexto. O sujeito não consegue modular o que ele acaba de dizer, nem se parafrasear, nem comentar, nem realizar um retorno reflexivo. Estes fenômenos demonstram, segundo Danon-Boileau, psicanalista e linguista, uma "palavra automática" na qual o pensamento não serve de mediador, uma vez que "a situação mobiliza diretamente $\mathrm{o}$ afeto ou a motricidade que fazem sair as palavras pela boca" (DanonBoileau, 2002, p.213). Ele a aproxima de xingamentos ou exclamações de surpresa que escapam ao locutor. As vocalizações involuntárias não representam o sujeito: elas constituem uma extração do gozo vocal equivalente a uma defecação sem sentido, a uma alimentação sem fome ou a um olhar largado no vazio. São constituídas de diversos S1 isolados. 


\section{A língua verbosa}

Em 1975, em uma época onde a representação mais frequente dos autistas era a de serem mudos, Lacan surpreende dizendo que os considera "meio verbosos": "Sua dificuldade em entendê-los, em dar alcance ao que eles dizem, segundo ele, não impede que sejam, segundo ele, personagens meio verbosos" (Lacan, 1985, p.20). Desta forma é destacada uma característica essencial de sua clínica: está em primeiro plano uma língua operando com S1 isolados. As vocalizações involuntárias e solilóquios da língua verbosa são feitos do mesmo material. Ambas são mobilizadas para satisfações solitárias e não para iniciar uma troca verbal. Foi o que constatou Melanie Klein a respeito de Dick, analisando de Melanie Klein, quando tinha quatro anos: "esta criança", dizia ele, "não tem o desejo de se fazer entender, não procura se comunicar, suas únicas atividades mais ou menos lúdicas são emitir e se comprazer com os sons sem significado, como ruídos" (Lacan, 1975a, p.95).

A língua verbosa encontra uma fonte maior na ecolalia: ela se alimenta de ecos do duplo, não das respostas do Outro. "A linguagem oral autística", observa Mottron, "quando aparece, é emprestada de situações não interativas (canções, propagandas, orações, créditos de televisão) e não imediatamente referenciadas" (Mottron, 2016, p.202). Quando a crianças autistas não são mudas, suas verbalizações originais sugerem a Kanner as noções de "linguagem de papagaio" ou "ecolalias extemporâneas". Às vezes, os pais notam que eles adquirem facilmente novas palavras mas nem por isso aprendem a falar, pois sua fala não carrega uma mensagem. O fenômeno é descrito por meio da observação de que a criança pronuncia palavras, mas não as utiliza.

À medida em que a criança avança na idade, a língua verbosa toma formas mais complexas, parece estar começando a aceitar ser direcionada, mas permanece fundamentalmente um solilóquio. Williams relata que era boa em leitura na escola, pois era uma "oportunidade para ela de deleitar-se com o som da sua própria voz de uma maneira mais aceitável que de hábito" (Williams, 1992, p.49). Com efeito, ela costumava atrapalhar a aula falando consigo mesma em voz alta.

Diziam [nas palavras dela]: que eu simplesmente amava o som da minha própria voz. Provavelmente estava correto. Talvez me achassem inteligente, mas eu não tinha nenhum bom senso. Eu menos falava com as pessoas do que fazia monólogos diante delas, como se toda conversa se resumisse a isso (Williams, 1992, p.44, p.50).

As emissões verbais autísticas podem ser mobilizadas para diversas utilizações, até mesmo como tentativas alusivas à comunicação, mas além das satisfações que ele entrega, suas funções maiores são de proteção: "uma ferramenta de dissimulação ou de ataque", conforme descrito por Williams (1992, p.140). Ela contribui para guardar o controle da pseudo troca e a manter o outro à distância. 
Acontece de emergir da língua verbosa séries regulares: "Thierry, quatro anos e quatro meses, relata Lemay, recita com um tom preciosista o nome de todos seus colegas de prématernal. José, quatro anos e um mês, faz a enumeração das múltiplas ruas que cercam sua casa" (Lemay, 2004, p.146). Tais esforços para discernir a ordem na linguagem e no mundo caótico podem conduzir o autista a tentar construir sozinho uma língua particular.

\section{As línguas particulares}

O autista não gosta dos equívocos da língua. Para se prevenir, quando procura se comunicar ele se apega a uma língua factual que ele gostaria que fosse tão precisa quanto um código, voltaremos a isso; mas às vezes ele elabora uma língua para o seu próprio uso. Ele supõe que ela seria mais apropriada à expressão de suas emoções ou, até mesmo, a melhor conduzi-los à "clareza". Annick Deshays emite a primeira hipótese: "Um autista raciocina de forma muito isolada", ela observa. "Ele joga com as palavras e ao mesmo tempo as codifica de acordo com seu estado emocional, ele fabrica seu dicionário" (Deshays, 2009, p.25). Sellin pende mais para a segunda:

encontrar magistralmente [ele escreve] uma língua simples essencial inteligível por todos, articulação ressoando como

seres de bruma

línguas contando com sensibilidade o que impede

os seres de bruma de atingirem a clareza da massa

humana gigantesca e segura (Sellin, 1998, p.117)

É claro que, quando ela é esboçada, o sonho de ela ser "inteligível por todos" logo se esvanece. No contorno do testemunho sobre sua vida interior, Sellin nos relata ter iniciado o esboço da elaboração de uma língua como essa.

Eu gostaria de contar hoje como acontece no lar que é muito 'tonukohass', eu vou deixar esta palavra ela significa não fique nervoso na linguagem sem complemento é uma linguagem para todos os, como dizer, tolos, eu inventei essa língua ela tem também uma gramática pessoal 'riokeea' significa então os cabelos da trança estão longos hoje (Sellin, 1994, p.86-87).

Esta língua particular, composta de neologismos, poderia possuir um dicionário e uma gramática, mas só seu inventor os conhecia, ela só entregaria ao ouvinte significados herméticos.

Desde as primeiras vocalizações das crianças autistas aparece uma tendência a criar uma língua particular. Mesmo quando compreendida por seus próximos, ela não é nem um pouco 
forjada para servir à comunicação: trata-se mais de uma busca de satisfações verbais solitárias levemente acompanhadas de uma busca de ordem e clareza. Assim, em torno de três anos e meio, Théo inventou uma língua neológica que seu círculo íntimo conseguia entender. Seus íntimos se puseram então a falar com ele nesta língua. Mas, sua mãe, Valerie Gray nos relata, "ele recusava que utilizássemos sua língua para responder a ele. Devíamos continuar a lhe falar como de hábito e ele nos responderia com sua linguagem reinventada" (Gay-Corajoud, 2018, p.95). Theo nessa circunstância se afirmava mestre de uma linguagem que ele tentava forjar, mas não compartilhar. Quando ele fez quatro anos, seu círculo pessoal e seu fonoaudiólogo começaram a tomar notas de sua língua particular. Fizeram dela um dicionário comportando cento e cinquenta palavras ${ }^{2}$. Dentre elas havia sete verbos e os vinte primeiros números, sendo que os substantivos são largamente dominantes. Certos termos são deformações do discurso do Outro (crocodilo/co-co-gli; bolo/ako) mas muitos são invenções sem relação com o objeto (livro/yiyi; sapato/ya-ya; cama/odo; pomada/ba). Duas características desta língua particular demonstram claramente que não se trata de uma lalíngua. Esta última segundo Lacan está sujeita ao equívoco (Lacan, 2001, p.490), ela só se sustenta de mal-entendidos e homofonias, de forma que é impossível guardá-la em um dicionário. De um lado, J.-A. Miller considera como característico de lalíngua ser de uma "multiplicidade inconsistente" (Miller, 1975, p.27), coisa que a língua particular de Théo não é, pois ela está organizada ao menos parcialmente, incluindo a série de números de 1 a $20^{3}$. Esta língua não comporta nenhum termo abstrato, o sentido de cada um dos elementos lá está fixado, referindo-se de maneira não ambígua a um objeto preciso. Ela procura impor ordem e clareza nos equívocos da linguagem. É de se notar que Theo não dá a ninguém o direito de utiliza-la: as satisfações que este objeto que ele inventou the dá são reservadas a ele. Ele não pretende dividilas. Provavelmente se o Outro viesse a usar sua linguagem, ela poderia ter sua clareza corrompida.

A língua de Theo está em conformidade com o que se observa nos autistas de Asperger de mais idade: ela foge dos equívocos e procura estabelecer séries regulares. Ela pode permitir uma certa comunicação com seu círculo, mas não foi feita para isso. Se alguns parentes conseguiram decifrá-la, essencialmente, é por que se ocuparam de fazê-lo, não por iniciativa da criança.

Línguas privadas mais complexas forjadas pelos autistas de alto nível, possuem as mesmas características: elas visam reduzir a ambiguidade da linguagem e constituem objetos de satisfações solitárias que as tornam pouco aptas à comunicação. Alguns autistas relatam ter experimentado, de início, uma língua particular como sendo sua "língua materna" ${ }^{4}$. Há casos, em que ela não é inventada, para Tammet ela já estava lá: desde sua primeira infância ele adotou a língua dos números. Ele possui uma percepção sinestésica de cada um destes, de sorte que the aparecem "como tantas formas, cores, texturas e movimentos. O número 1, por exemplo, escreve, é de um branco brilhante e luminoso, como alguém que dirige o facho de uma lanterna diretamente para meus olhos" (Tammet, 2007, p.11). Cada elemento de sua língua materna é um objeto complexo, que suscita diversas percepções. As características destas são estabelecidas para dar forma aos 
tais objetos, de forma que os números de Tammet podem ser apreendidos um por um, independentemente de seu valor diferencial; por este motivo ele é capaz de fazer cálculos combinando suas formas. Essa língua particular é carregada de um gozo excepcional e lhe incita diversas emoções. Quando recitou os 22.500 decimais do número Pi que havia memorizado, ele teve o sentimento, nas suas palavras, de ter sido o "porta-voz de Pi" (Tammet, 2018). A língua dos números é um objeto ao qual ele empresta sua voz; não é uma língua subjetivada. Ele confirma esta informação quando observa que não sabe de onde vem o sentido que se associa a esta língua: constata que Quarta-Feira é um dia azul, mas não está apto a dizer por quê. Ela certamente lhe dá o sentimento de estar às voltas com suas emoções, mas ela não as expressa: ela as suscita. Ele não desconhece que ela seja imprópria para transmiti-las. Quando Tammet recita um poema de números que ele compôs, sua emoção é patente, mas ela permanece obscura aos ouvintes. A língua dos números não é uma lalíngua, mas sim um objeto que fornece satisfações solitárias, portador de um sentido ao qual o sujeito consente, mas pelo qual não pode comunicar sua vivência. Trata-se, além disso, de um objeto que se presta a manipulações notáveis que lhe permitem fazer surpreendentes memorizações de impressionantes cálculos. Para que ela se preste a fazê-lo, é necessário, certamente que ela não tenha nada de multiplicidade inconsistente e que seus elementos não sejam sujeitos a equívocos.

Com sua outra língua particular, o Mänti, Tammet procura falar uma "língua bem dele, que seria uma expressão tangível e comunicável de [sua] intimidade" (Tammet, 2007, p.182). Entretanto, todos os exemplos fornecidos se referem a palavras que designam objetos ou abstrações (Tammet, 2007, p.181) - nenhum, a sentimentos ou experiências corporais. Os termos do Mänti são forjados de forma a ter uma certa afinidade com as coisas designadas. A palavra Mänti, escolhida para nomear esta linguagem, é construída a partir do finlandês mänty, "pinho, por que os pinhos crescem frequentemente em grupos numerosos e simbolizam a amizade e a comunidade" (Tammet, 2007, p.181). Por outro lado, Tammet inventa palavras que, por um certo isomorfismo estabelecem novas ligações entre as coisas, por exemplo hamma (dente) e hemme (formiga - um inseto que morde). O Mänti é frequentemente criado por um trabalho de escrita feito a partir de diversas línguas estrangeiras. Seu "vocabulário de mais de mil palavras" (Tammet, 2006/2007, p.181), não se ancora em equívocos, além disso, ele possui uma gramática com duas características que o distinguem nitidamente de uma lalíngua. Levar em conta os dados visuais e concretos parece de suma importância em sua criação, de forma que ela se mostra pouco apropriada a expressar os dados mutáveis e sutis dos sentimentos e dos ressentimentos. Além disso, ela permanece imprópria a comunicação: Tammet é o único a compreender o Mänti, língua que ninguém fala, língua sem Outro.

O referente é inequívoco no que diz respeito aos signos do Mänti ou aos da língua de Théo, enquanto os números de Tammet constituem "um vocabulário numérico e visual" que é próprio ao seu criador (Tammet, 2007, p.13). Cada termo da língua particular é portador de um 
sentido definível. Ao contrário, em lalíngua, os significantes estão à espera de um sentido, que só advém por uma articulação ao S2. Os elementos da língua particular não têm esta espera de outros elementos que viriam determiná-los. Eles parecem bastar-se a eles mesmos.

A língua particular às vezes gera neologismos, mas são de uma natureza bem diferente dos forjados pelos paranoicos. As produções destes têm um significado evidente, que os torna aptos a comunicar sem perder a própria coisa. Já os autistas se inserem frequentemente em uma língua secreta criada por eles próprios, que não tem a função de servir de comunicação. Os paranoicos procuram fundar com os neologismos uma língua universal; enquanto os autistas os dissimulam em uma língua particular.

Uma das formas elaboradas da língua particular se constrói com os significantes apropriados a compor um interesse específico. Um gozo intenso se associa à apropriação destes significantes e ao conhecimento de seus ordenamentos.

Só posso falar por mim [escreve Luke Jackson, um autista portador de Asperger], mas quando eu estou com alguma coisa na cabeça, todo o resto do mundo para de existir. Suponho que isso pode ser taxado de egoísmo e eu estou realmente me esforçando para pensar mais nos outros; mas muitas vezes isso é muito difícil. Quer se trate de dinossauros (quando eu era menor, quero ressaltar), Pokemons, playstations ou computadores - estes exercem uma fascinação recorrente sobre mim - eu sinto uma tamanha onda de excitação subir em mim que eu não consigo descrever. Eu preciso absolutamente discutir o assunto, ser cortado na minha fala me coloca em um estado tal que eu posso facilmente entrar em uma raiva louca. Escrevendo isso tudo eu me dou conta de a que ponto pode parecer loucura, mas só estou descrevendo a realidade (Jackson, 2007, p.41).

O autista tenta dar testemunho de seus conhecimentos relativos ao interesse específico, mas na verdade seu extremo investimento o conduz inicialmente a escapar da troca e a se separar dos outros. "Você já percebeu [perguntamos a um deles] que ao longo de um certo tempo as pessoas se cansam e tentam falar de outra coisa"? Ele responde: "Eu sei disso bem, é o motivo por que não tenho amigos, mas eles precisam me escutar, ou então não são nada para mim" (Lemay, 2004, p.148). Lá pelos dez anos, Tammet ainda não tinha consciência de estar importunando aqueles a quem relatava seus centros de interesse, seu testemunho corrobora esta afirmação:

Quando eu falava com alguém frequentemente, o fazia de uma vez só, sem parar. A ideia de fazer uma pausa ou de ceder a palavra não me vinha. [...] Eu não compreendia que o objetivo de uma conversa não é falar unicamente das coisas que me interessam. Eu falava com muitos detalhes, até ser esvaziado de tudo o que eu tinha para dizer. Eu sentia que eu poderia ter explodido se alguém tivesse me interrompido. Nunca me ocorreu que o 
assunto do qual eu falava poderia não ser interessante para meu interlocutor. Eu também não notava se ele começava a demonstrar impaciência ou lançava olhares em torno dele.

Eu continuava a falar até que me diziam alguma coisa do gênero: Preciso ir embora agora (Tammet, 2007, p.85).

O autista parece ser levado a se comunicar a partir de seu interesse específico; mas de fato, os significantes que o compõem são inicialmente utilizados para barrar a interlocução. Seu intenso investimento libidinal é inicialmente colocado a serviço de monólogos, testemunhando sua natureza de S1 solitários.

Apesar das línguas privadas entrarem em ressonância com o corpo, suscitando mais do que traduzindo emoções, elas não são lalínguas verbosas. São constituições originais buscando a ordem e a clareza. Elas são impróprias para a troca, não se baseiam numa cessão da voz, não incluem a função do significante-mestre: ora Tammet ignora de onde vem seu significado, ora ele a inventa, nos dois casos ela se mostra solipsista, só vale para ele próprio. A língua particular é uma língua de S1, ela não poderia fazer laço social, mas não é uma lalíngua inconsistente, em razão de esboços de construções e ordenamentos que lhe são próprios.

\section{A língua factual dos signos fixos}

Apesar da importância assumida pelo S1 solitário na fala do autista, ele não é um exilado da troca verbal, não é sempre verboso nem sempre hermético. Williams nos indica duas utilizações possíveis de palavras, na primeira, aquela sobre a qual acabamos de elaborar, prima um gozo solitário do sonoro; na segunda, eles se tornam, segundo sua expressão, "suportes de acumulação de fatos" (Williams, 1994, p.169). Esta clivagem operada pelos autistas no tratamento da palavra foi muito notada. A língua verbosa predomina nos autistas de Kanner; enquanto a outra língua maior, a língua factual, conhece seus desenvolvimentos mais elaborados nos autistas de Asperger. Na clivagem demonstrada por Williams em sua construção subjetiva, a língua factual, muitas vezes chamada de funcional, é oriunda da sua parte que se dobrou à educação que lhe foi imposta, isto significa que ela está às voltas com o discurso do Outro, enquanto a língua verbosa pertence ao seu universo pessoal "completamente cortado do resto do mundo" (Williams, 1992, p.274).

Quais são as características da "língua de acumulação de fatos" evocada por Williams? Partamos de um exemplo relatado por Kantzas. Georges repete uma breve historieta:

O caçador de peles se levanta cedo pela manhã. Ele sai de casa com seu fuzil e muitos cães para ir à floresta. Quando os cães veem a raposa eles se põem a latir. O caçador apoia seu fuzil, atira e mata a raposa. O caçador vai em seguida ao mercado para vender a pele da raposa que serve para fazer roupas de pele (Kantzas, 1987, p.121-122). 
Essas sucessões de fatos, sem comentários, sem afetos, parecem visar uma simples apresentação das coisas, sem implicação da voz enunciativa. Uma outra observadora destes fenômenos nota que tais palavras se mostram essencialmente de "natureza constatadora" e não intencional. Aubin por exemplo, não podia dizer que um dos seus colegas havia sido punido pela professora por ter sido malvado. As observações desta criança, relata B. Donville, "se respaldavam nos mínimos detalhes, mencionando a cor do casaco do colega, observações que ele proferia inopinadamente, sem que nada de particular lhe tivesse sido perguntado" (Donville, 2006, p.68). Notamos a subsistência de um elemento de monólogo em palavras direcionadas a um interlocutor.

Ele se plantava simplesmente diante da mãe para informá-la e em seguida se calava sem nada mais adicionar. Nada na sua linguagem contava, descrevia ou tentava deduzir, no melhor dos casos, se obtinha dele considerações pontuais das quais ele nunca extraía nenhuma consequência (Donville, 2006, p.68).

Tais palavras se mostram muito diferentes da verborragia: elas se inscrevem em um esforço para comunicar, motivo pelo qual precisam ser produzidos na língua do outro. Além disso, o gozo da voz se encontra apagado enquanto ela se afirma na verborragia.

Uma das particularidades da língua factual dos autistas, sublinhada por todos os especialistas, reside no emprego maciço de substantivos, categoria linguística que exprime simplesmente a existência das coisas. A ancoragem na concretude que ela demonstra, parece provir da preocupação de essencialmente só usar palavras que tenham por referente um objeto discernível na realidade. Observadora atenta da linguagem de sua filha autista, Clara Park determina:

Quer fossem concretos ou abstratos, ele captava imediatamente todas as palavras absolutas, aquelas que expressavam conceitos definíveis e compreensíveis entre eles. "Caixa", "gato", "girafa", "retângulo", "número", "letra". Por outro lado, ela era incapaz de entender as palavras que definem relações, as que só encontram seu pleno sentido em uma situação onde o elemento humano faz um papel (Park, 1972, p.216).

Existem de fato muitas palavras que necessitam ser apreendidas em um contexto e em uma relação com outras palavras para que possam ser compreendidas. Não se pode, por exemplo, definir pequenez ou grandeza absoluta. De fato, desde Saussure, sabemos que "na língua só há diferenças": o signo, o significante e o significado só se definem em sistemas de oposições diferenciais e interdependentes. Disso resulta que o significado de um elemento só advenha da sua relação com outros, o que implica um trabalho subjetivo, um exercício do julgamento ao qual o 
autista de Kanner não se arrisca. Ele se orienta para uma linguagem que descreveria os fatos sem que ele mesmo tenha que interpretá-los. Desde logo, seu ideal é um código que seria capaz de conectar as palavras de forma constante e rígida em objetos e situações claramente determinadas.

Não é a complexidade de uma língua que causa problemas para os autistas [explica $\mathrm{K}$. Nazeer], de fato é provável que ela os ajude, uma vez que quanto maior ela for, menor será o risco de uma palavra ser polissêmica. Quanto mais regras e estruturas existirem, mais um autista precisará confiar em sua intuição e no contexto (Nazeer, 2006, p.26).

O ideal para eles, ressalta o autor, seria "um sentido/uma palavra" isto é uma língua que se reduziria a um código, de início totalmente construído por signos.

\section{Ancoragem do signo na situação de aprendizado}

Uma das características iniciais da língua factual reside na permanência da situação original de aprendizagem. Kanner logo percebe o fenômeno. O pai de Don, relata ele, tenta ensinar ao filho o uso do "sim" e do "não". Ele lhe pergunta: "Você quer que eu te coloque em cima dos meus ombros?" Don repetia a pergunta como um eco, o que significava seu acordo. Seu pai então Ihe diz: "Se quiser diga 'sim', se não quiser diga 'não'". Don pronunciou o "sim" esperado pelo pai, que o colocou nos ombros. Mas, infelizmente, Don por anos, só disse sim estendendo os braços para os ombros do pai. "Sim" só significava isso para ele (Kanner, 1983, p.221).

Os autistas de Kanner, Grandin constata, "são incapazes de assimilar qualquer afastamento em relação às imagens que estão armazenadas em sua memória" (Grandin, 1997, p.184). Ocorre a eles a criação de palavras, que só são compreensíveis se conhecermos a situação que as originou. Durante o desenvolvimento da linguagem de seu filho, Thomas Hilde De Clerq foi surpreendido ao constatar que ele inventava palavras para nomear objetos que tinham a mesma função, mas não exatamente a mesma aparência. Ele usava diferentes nomes para designar uma "bicicleta". Ele possuía uma "bicicleta", um "trator", "rodas na lama", "rodas na grama" e "pezinhos nos pedais". Sua mãe comenta: "Todos o consideravam muito criativo, mas eu tinha dúvidas, achava que ele não conseguia fazer de outro jeito". Quando eu Ihe dizia: "Vá dar uma volta de bicicleta", ele não entendia, pois nesse momento só via "pezinhos nos pedais". Para ele, a palavra bicicleta ainda não possuía sentido geral (De Clerq, 2005, pp.22-23).

Devido a uma relação de aderência que existe entre as expressões da língua factual e a situação onde inicialmente foram cunhados, seu significado tende a ficar estático. Uma língua neste formato realiza uma codificação da realidade. Ela realiza o ideal: uma palavra/um sentido. Não só a palavra deve ser unívoca, mas as coisas propriamente ditas também não devem mudar de denominação.

Os linguistas constatam que as crianças aprendem logo que uma coisa pode ter diversos 
nomes, que o cão é um animal, e pode se chamar Médor e também pode se chamar Toutou. Isso não parece causar-Ihes maiores problemas. "Eles esperam que um pai seja também um senhor, e que se chame Pierre ou Paul, ou, 'meu querido'" (Boysson-Bardies, 1996 p.158). Entretanto, isso não é óbvio para uma criança autista. Para eles, quer o signo seja sonoro ou escritural, ele permanece por muito tempo correlato a uma determinada experiência. É o que explica que a memória musical formidável de determinado autista encontre sempre o mesmo erro inerente à primeira audição, ou que um erro de ortografia seja sempre reproduzido pois estava presente no primeiro texto no qual a palavra foi encontrada. A dificuldade do autista em generalizar se ancora na rigidez do signo lastreada pela persistência da situação de aprendizado, de forma que ele está pouco apto a se modificar junto com o contexto. "Se eu aprendesse alguma coisa com uma mulher em um dia de verão", Williams relata, "a lição não evocaria nada se fosse reproduzida em outro local com um homem em uma noite de inverno" (Williams, 1994, p.91). Por esta razão, mesmo captada na língua do Outro, a língua factual permanece compatível com radicais incompreensões na troca, resultando que a informação seja tomada de forma muito literal.

Um dia em que eu estava sendo admoestado por ter feito desenhos na parede do parlamento durante uma excursão [Williams nos informa], eu prometi não fazê-lo novamente. Dez minutos mais tarde, me surpreenderam reincidindo na parede da escola desta vez. Eu não tive o sentimento de ter desobedecido ou falhado na minha promessa só pelo prazer de me fazer de palhaço: o que valia para as paredes do parlamento, para mim não valia para as paredes da escola. Eu não havia feito exatamente a mesma coisa que antes. Era tudo. (Williams, 1992, p.115).

Os autistas ficam paralisados por muito tempo em signos que não podem ser relacionados nem a um referente concreto, nem a uma imagem. Todos constatam que os termos sintáticos e as conjugações thes são difíceis de abordar. A partir do momento em que a noção descola do referente para passar de um elemento a uma generalidade, a compreensão do autista encontra um obstáculo:

Eu sempre tive a maior dificuldade [informa Williams] em conceber a transformação de uma coisa em outra. Eu sabia o que eram as vacas, mas quando elas se transformavam em rebanho elas deixavam de ser vacas para mim. Eu entendia bem que a palavra 'rebanho" designava um conjunto, mas eu ainda não tinha nenhuma ideia do que poderia significar a palavra "gado". Também era assim com a palavra "pele". Uma vez costurada, era apenas um tipo de estofo que nunca foi um animal e não poderia tê-lo sido (Williams, 1994, p.133). 
É possível conceber que os termos lhe sejam de difícil abordagem.

\section{A não incorporação do signo na língua factual.}

A adesividade do signo ao referente o torna impróprio a codificar afetos que se expressam de forma diferente em cada um, que possuem nuances, que são muitas vezes fugitivos e mutáveis, e que é difícil de objetivar. É de se notar que as primeiras palavras expressivas das crianças autistas sejam mais frequentemente termos que designam objetos e não manifestações emocionais. "Tais crianças", define Williams, "são secretamente capturados em uma afetividade mutilada; eles têm sentimentos e sensações, mas que se desenvolveram no isolamento. Eles não conseguem verbalizá-las de forma normal" (Williams, 1994, p.301). "O cérebro", confirma Harrison, "não recebe as mensagens do corpo, mesmo se o cérebro e o corpo fazem seu trabalho cada um do seu lado" (Harrisson, 2010, p.311). Disso resulta uma falta de espontaneidade e de iniciativas pessoais que constrangem os autistas a observarem os comportamentos sociais para tentar remediar a separação entre seu intelecto e seu ser de gozo.

Quando criança [Grandin relata] eu era como um animal sem nenhum instinto para se guiar; eu tinha que aprender tudo por aproximações sucessivas. Eu passava meu tempo observando e procurando o melhor comportamento possível mas isso nunca colava. Eu tinha que pensar em cada interação social (Grandin, 1997, p.154).

Quando se tornou adulta, Grandin não hesita em comparar sua maneira de pensar à de um computador. Nas palavras da autora:

recentemente eu assisti a uma conferência [ela conta em 1995] onde uma socióloga afirmava que os seres humanos não falavam como computadores. Na mesma noite, no jantar, eu contei a essa mesma socióloga que o meu modo de pensar se assemelhava muito ao de um computador, e que eu podia explicar o processo, etapa por etapa. Eu fiquei um pouco chocada quando ela me respondeu que ela era pessoalmente incapaz de me dizer como seus pensamentos e emoções se encadeavam. Quando ela pensava em algo, os dados objetivos e as emoções formavam um todo. [...] no meu espírito, eles são sempre separados (Grandin, 1997, p.162).

Um autista Asperger utiliza uma fórmula impressionante para descrever um constante trabalho de intelecção cortado da vivência para se orientar na vida social: "pensar sua vida e viver seu pensamento" (Damaggio, 2011, p.168).

Todos os autistas que possuem suficiente distanciamento para avaliar seu modo de funcionar constatam, assim como Tammet, que durante muito tempo eles não compreenderam 
suas emoções. "Eram coisas que me aconteciam", nas palavras dele, "vindas de lugar nenhum" (Tammet, 2007, p.118). Eles insistem na sua própria incapacidade em captar e expressar o gozo e a vida emocional pela linguagem. "Eu podia dizer o que eu pensava", Williams afirma, "[...], mas não o que eu sentia [...] estava emocionalmente constipada" (Williams, 1992, pp.88-89).

As emoções experimentadas pelo autista inicialmente não são interpretadas pelo signo. "Meu rosto ficou molhado", Tammet relata, após a morte de seu cão, "e eu soube que estava chorando (Tammet, 2007, p.165). É em um segundo momento, numa relação externa ao corpo, que a emoção ganha sentido. Muito exatamente o que descreve Harrisson: "Os autistas têm emoções, mas precisam importar seu sentido do externo para que possam acessá-las conscientemente" (Harrisson., 2010, p.241). O resultado disso é que as emoções são aprendidas de maneira intelectual.

Eu quero que me ensinem emoções [D. Williams pede a uma família de amigos]. Graças a linhas e esquemas, eu vi a escala raivosa, a escala feliz e a escala triste. Nestas linhas, eles marcaram as variantes inferiores e superiores: cansado, ocupado, enervado, agitado, irritado, chateado e furioso. Em seguida tentaram me mostrar como cada estado podia traduzir-se em um rosto ou se refletir em ações" (William, 1994, pp.161-162).

A comparação com a assimilação de um programa de computador se thes impõe fortemente, para ressaltar a aquisição de um saber pré-fabricado apartado de seu substrato sensível. "Assim como arquivos de informática", Williams anota, "podemos mentalmente memorizar os jogos das emoções, extraí-los e interpretá-los". Entretanto, ela percebe os limites deste processo imitativo quanto à sua apreensão subjetiva.

O jogo [ela ressalta], não está ligado a um sentimento real e nós não necessariamente compreendemos a emoção representada, salvo pelo mecanismo do modo, e às vezes do momento de sua imitação. [...] Uma ideia nunca é um sentimento, simplesmente a lembrança ou o repertório mental memorizado de sua impressão (William, 1994, pp.288289).

Desde logo, a não incorporação da língua factual, como o elemento fora do sentido da língua verbosa, vêm ao apoio da tese dos Lefort, segundo a qual, "na estrutura autística, o significante falha em tornar-se corpo e falha assim em produzir afeto" (Lefort \& Lefort, 2003, p.87).

\section{A difícil contextualização do signo.}

Os significantes são capturados na primeira abordagem em uma cadeia que os organiza; 
enquanto os signos da língua factual são inicialmente apreendidos um a um. Quando a percepção é estruturada por esta língua, ela carece de coerência, ela aparece como um "quebra-cabeças". "É assim que eu via as coisas", relata Williams, "pedaço por pedaço, como uma cadeia de elementos desencontrados reunidos arbitrariamente uns aos outros" (Williams, 1992, p.31). Um difícil trabalho Ihe "é necessário para que ela consiga juntar os pedaços do quebra-cabeças" (Williams, 1994, p.121).

Mesmo quando os autistas chegaram a uma certa organização dos signos memorizados, eles descrevem frequentemente sua percepção como "fragmentada". No entanto, o autista Asperger para de ter uma atitude passiva em relação aos signos memorizados: ele evolui para conseguir mobilizar as coerências locais. Gerland relata seus esforços para remediar à fragmentação de seu mundo, tentando por ordem no seu saber. Ela relata:

eu tinha o hábito de escrever etiquetas para diversos objetos. Eu queria que tudo fosse triado, distinguido, separado [...] para tentar ordenar o mundo exterior segundo o mesmo sistema que o meu mundo interior. [...] já havia em mim um processo de compartimentalização acabado, munido de etiquetas para as ações, os espaços e os universos. Em verdade, assim como um computador, havia muitas ramificações e bifurcações, mas poucas ligações transversais. Estava perfeitamente claro que o mundo que me cercava seria mais acessível se eu pudesse fazer, nele também, uma triagem deste tipo. Eu redigia então etiquetas falando da natureza de cada objeto e do lugar que ele devia ocupar '(Gerland, 2004 p.52).

A apropriação dos signos se faz inicialmente elemento por elemento. Segundo Harrisson, a memorização se opera a partir de um "dado isolado" ou, segundo Dawson, "ela se apoia em um elemento indivisível de informação" (Mottron, 2004, p.193). Nos autistas mais graves, este elemento pode ser constituído por palavras, mas para os autistas de Asperger, ele toma, às vezes, a forma de uma destas coerências locais, sobre as quais Gerland coloca definições. O registro dos elementos é mais complexo do que os de fotografias: a percepção destes sujeitos, constata Mottron, "não é estática, ela pode ser multimodal (sinestesias) e autoriza manipulações sobre o material memorizado" (Mottron, 2004, p.186). Ocorre efetivamente que os signos são guardados em conjuntos organizados de diversas formas próprias a cada um. A coerência percebida da ordem das coisas e de suas regularidades é uma delas. Além disso, Grandin relata dar um lugar de destaque para a ordem cronológica ${ }^{5}$ para classificar sua "videoteca mental"; outros recorrem à imagem de um quebra-cabeças em permanente construção, outros ainda, a um mapa geográfico ou a um banco de dados, etc. Parece ser necessário entender que cada termo toma seu lugar em um conjunto, comparável a um fichário e que tudo é suficientemente organizado para que o sujeito possa mobilizar a informação. 
Harrisson dá uma descrição muito detalhada das especificidades de sua memória. Ela a descreve como sendo uma fragmentação coerente, que apresenta as seguintes características:

a gravação de cada dado" [ela relata] "é muito precisa e se faz por uma estrutura estática. Cada imagem é minuciosamente diferenciada das outras. Todos os detalhes de cada um dos dados são retidos da forma que são percebidos. Sem nenhuma nuance. E cada dado é isolado no início para ser classificado em seguida, mas guardando sua independência. A gravação é comparável à realização de um quebra-cabeças. Ao final, vemos todas as peças únicas que nos permitem em seguida ver a imagem global. As peças são associadas e não interagem. A imagem global do quebra-cabeças - também chamado de "mapa geográfico" - se expande à medida que, segundo a quantidade de peças que conseguimos reunir, ou seja, as peças nas quais encontramos um sentido que possa ligá-las as outras. Estas pequenas imagens globais constituídas de diversos fragmentos de informação, muito bem definidos uns em relação aos outros, se fundem em um grande mapa geográfico a cada gravação (Harrisson, 2010, p.91).

Ouellette retém a imagem do quebra-cabeças para descrever o lento ordenamento dos signos memorizados operado pelo autista de alto nível:

Este trabalho [ele afirma] se compara a montagem de um quebra-cabeças de mil peças sem dispor do modelo impresso na caixa. Ao longo do tempo as partes são reunidas, mas a imagem global ainda não aparece. Por fim acabamos tendo 'ilhas' suficientes do quebracabeças para enfim reconhecer a imagem no seu conjunto e todas as partes acabam por encontrar seu lugar (Ouellette, 2011, p.181).

Ele é capaz de descrever com grande fineza as diferenças maiores no funcionamento, distinguindo o do sujeito "típico", cujo pensamento é comandado pelo significante-mestre e o do sujeito autista, que pena para articular signos justapostos.

De uma certa maneira, ele nota, a cultura neurotípica é ondulatória, enquanto a cultura Asperger é corpuscular. O pensamento neurotípico procura unir rapidamente, quase simultaneamente, as informações provenientes de diferentes sentidos e emoções, a fim de construir rapidamente um sentido no mundo, visando extrair um benefício de curto prazo. [...] O pensamento Asperger trata essas informações de forma lenta e sucessiva, donde o fato de os autistas Asperger se interessarem mais aos detalhes do que aos conjuntos. Como um raio laser, seu pensamento se concentra primeiro em pontos. [...] Um Asperger age assim para deixar emergir progressivamente o sentido da lenta soma dos detalhes 
(Ouellette, 2011, p.184).

O caráter discreto do signo só dá acesso a uma memorização fragmentada, que certos autistas, graças a um trabalho mnemônico intenso apoiado na visualização, são capazes de tornar mais ou menos coerente. As crianças típicas não têm esta dificuldade. Os elementos pelos quais se estrutura seu pensamento e seu ser são situados em conjuntos estruturados. Os significantes segundo Saussure estão sempre inseridos em "uma cadeia" (Saussure, 1972, p.103), eles se reúnem em uma sincronia regida pelas leis da gramática, que é espontaneamente assimilada no seu aprendizado. Por este motivo, os linguistas consideram que entre os dezoito e os vinte e quatro meses, as crianças típicas são verdadeiros "gênios gramaticais". É nessa idade que eles fixam o sistema gramatical que governa sua língua. Ora, é de se observar que o gênio gramatical vem ao sujeito por exposição à linguagem e não pelo seu aprendizado. Lacan pontuava que este fenômeno faz objeção à psicologia genética na sua abordagem do sujeito: "A criança", ele constata, "desde suas primeiras manifestações da linguagem, se serve da sintaxe e das partículas de acordo com as nuances que os postulados da 'gênese mental' só deveriam lhe permitir atingir no ápice de uma carreira de metafísico" (Lacan, 1966, p.142). Os linguistas estão de acordo em considerar "que o essencial da gramática é conhecido antes de ser ensinado, pois ela é uma parte essencial de nossa capacidade de nos expressarmos" (Boyssin-Bardies, 1996, p.218). A maior parte dos estudos demonstra que há poucas correlações entre a linguagem da mãe e o desenvolvimento linguístico da criança. Os pais "não ensinam" a língua às crianças; eles lhes fornecem modelos (Boyssin-Bardies, 1996, p.110). Ela não se aprende como a tabuada, e sua aquisição não exige a participação do pedagogo.

Uma gramática como essa, adquirida sem aprendizado, inerente à organização sincrônica da cadeia significante, está manifestamente em falta na criança autista. O discurso sintético deste utiliza muito poucos termos como "por que", "pois" e "por conseguinte".

Quando criança [Grandin relata] eu omitia palavras como "é", "o", ou "este", pois isolados não significavam nada para mim. Da mesma forma, palavras como "de" e "um" me eram incompreensíveis. Acabei por aprender a empregá-los corretamente por que meus pais falavam bem e eu imitava as formulações de suas frases. Ainda hoje, algumas conjugações como a do verbo "ser" não fazem o menor sentido para mim (Grandin, 1997, p.33).

A aquisição de conceitos relativos, Peeters comenta, é difícil para os autistas, "pois palavras como 'grande', 'pequeno', 'largo', 'estreito', 'seguro', 'do outro lado de', 'depois', 'dar', 'pegar', ganham, seu sentido a partir do contexto, considerando a relação que elas têm com as outras palavras da frase". Ele observa, muito corretamente, que para explicar a uma criança autista os conceitos de "grande" e "pequeno", "seria necessário poder the comunicar seu 
significado a partir de uma percepção "literal": isto é "pequeno" em absoluto, e aí pode-se compreender o sentido invariável de "grande". Infelizmente isto é impossível (Peeters, 1996, p.68).

O que ele denomina "percepção literal", nós ressaltamos, é sobretudo uma percepção visual, até mesmo táctil. Todos os autistas constatam que as palavras que não podem ser relacionadas a uma imagem lhes são difíceis de compreender.

\section{A língua factual dos signos ordenados.}

As primeiras aquisições do signo se operam de forma estática; contudo, quando as capacidades do sujeito se desenvolvem, ele se torna, aos poucos, capaz de mobilizá-las. "O autista", Harrisson indica a este respeito, "não tem acesso ao ordenamento sozinho, salvo se tiver atingido um nível suficientemente elevado (tendo ganhado acesso ao movimento, à interação)" (Harrison, 2010, p.85). Neste ponto ele se mostra à altura de descolá-los de sua rígida conexão com o referente. Através da interação os signos ordenados se tornam menos fixos e tendem a se destacar da situação de aprendizado. Não são mais, apenas, termos-etiqueta, o sujeito os organiza em sua memória de uma maneira que Ihe é própria, e que lhe permite colocá-los em relações de oposição mútua. Quando Grandin é obrigado a recorrer a ícones tais como "uma pomba ou um cachimbo", para representar-se a noção abstrata de paz, não é só por acoplamento destas palavras à imagem de um referencial: ela os insere em relações de oposição com outros pássaros com a pomba e, para o cachimbo, com outros objetos que servem para fumar.

A fixidez inicial do significado do signo tende a ser atenuada progressivamente com a ajuda de um intenso trabalho de memorização. Graças a este, advém uma certa flexibilidade de seu uso. Não sem resistência, o autista adquire a noção de que um mesmo objeto pode ser designado por signos diferentes, que a localização do objeto não é rígida e até mesmo que convém distinguir a coisa e sua imagem.

Mohamed se zangou [F. Hody nos relata sobre este assunto] por que nós persistíamos em dizer "carro" no lugar de "automóvel". Custou-lhe uma noite para admitir que duas palavras diferentes poderiam designar um mesmo objeto. Ao final ele foi capaz de nos explicar que podemos dizer "automóvel" ou "carro" e é a mesma coisa. Uma porta batida e cinco minutos emburrado serão suficientes para que ele aceite que haja girafas no zoológico e na África, mas em seguida a dificuldade será exatamente a mesma para as zebras. Sobre o leão da marca Peugeot, é Wanda quem Ihe emprestará a solução: não se trata de um leão, mas sim do "desenho" de um leão (Hody, 2008, p.174).

O ordenamento mnemônico dos signos é organizado no autista segundo uma lógica espacial: os modelos evocados são o mapa geográfico, o quebra-cabeças, a arrumação de CDroms e um balizamento por meio de etiquetas. A estruturação da memória resulta de um esforço 
voluntário, ela se organiza a partir do visual e ela não é comandada por elementos inconscientes. O sujeito afirma estar na presença imediata da arrumação de informações memorizadas. Os elementos de sua memória permanecem ancorados na percepção. Em compensação, a memorização que se apoia no significante não é visualizável: ela é regida por uma gramática préconsciente, assim como por um gozo ligado no inconsciente aos significantes-mestres ${ }^{6}$.

Por falta de aquisição espontânea da gramática inerente ao sistema significante, os autistas são obrigados a aprendê-lo essencialmente pela memorização. Eles conseguem fazê-lo muito bem. Suas aptidões mnemônicas são tamanhas que muitos autistas Asperger possuem um excelente domínio de sua língua, até mesmo de várias línguas. Não são gênios gramaticais, é exatamente o motivo pelo qual, a fim de compensar a dispersão dos signos, eles se transformam em gênios mnemônicos.

É possível que a propensão do autista para a colocação em imagens, seja um dos elementos que o levam a representar o local de sua dinâmica em um objeto que aparelha seu gozo. Este último é tão específico, que a clínica impôs a introdução de novos conceitos para definilo: "O objeto autístico" de Tustin, o "interesse específico" dos modernos manuais de psiquiatria, e "a borda" para a abordagem lacaniana. Essa última constitui a construção defensiva maior para o autista que procura sair de sua solidão. Com a retenção dos objetos pulsionais e a alienação que se opera sem a ligação ao significante-mestre, ele caracteriza a estrutura autística.

\section{Aparelhagem do gozo pela borda}

Os psicanalistas que trabalharam com crianças apresentando formas graves de autismo constatam de maneira concordante que elas se preocupam muito com buracos, quer sejam os do seu próprio corpo ou os do ambiente.

A primeira criança autista que eu pude tratar no hospital, após fugir pelos corredores, começava invariavelmente as sessões tampando com massa de modelar, todos os buracos da sala, até mesmo seu próprio umbigo. Não é raro fazer uma observação como esta. Os autistas prékannerianos se preocupam particularmente com buracos, tanto os do seu corpo quanto os do meio em que estão. Os buracos dos sanitários ou dos lavabos suscitam frequentemente suas inquietudes. Éric Laurent sublinha uma intolerância ao buraco nos autistas (Laurent, 2012. p.68). O encontro destes mobiliza angústias de separação, donde sua propensão a tapá-los; ao mesmo tempo a materialização de uma perda é sentida, segundo Tustin, como um buraco negro cheio de criaturas ameaçadoras (Tustin, 1992, p.238). Malika confirma essa afirmação quando, confrontada a um buraco em uma cadeira, ela se interroga, inquieta, "a boneca desmontada não vai sair desse buraco, se você7 não tapá-lo?" Desta forma ela se põe a fechar o buraco com massa de modelar, comentando: "eu tapo o buraco para que não chegue boneca desmontada nele". Em uma sessão anterior, ela me contara: "Perder seu cocô é ser desmontada", em outro momento ela se interrogava: "Quando a boneca é desmontada, ela tem buracos?" Malika não elegeu um objeto 
autístico. Entretanto, a massa de modelar usada como tapa-buracos parece assemelhar-se à função de carapaça deste objeto tal qual Tustin o concebia.

\section{Nascimento da borda}

A insistência desta psicanalista inglesa sobre um processo de encapsulamento através da construção de objetos produzidos pela criança autista, incitou Éric Laurent, desde 1992, a considerar que o retorno do gozo sobre uma borda (Laurent, 1992, p.156) constituía um elemento maior do funcionamento autístico. Entretanto, a apreensão deste objeto autístico por Tustin como algo que faz obstáculo a uma assunção da perda, o conduziu logicamente a considerá-lo como objeto patológico. Ora, muitas encarnações da borda, carro, ventilador, máquina de lavar, chaves, etc., não induzem a privilegiar a imagem da carapaça. De fato, parece que a carapaça arrisca-se a induzi-lo a erro.

Perceber o nascimento clínico de uma borda, é um meio privilegiado para discernir suas funções. A este respeito, Bettelheim e Tustin recolheram dois documentos excepcionais. O primeiro percebeu o momento decisivo no progresso de Laurie, uma boneca flácida e muda de sete anos, quando ela se pôs a rasgar papéis em longas fitas e fazer fronteiras. "Foram suas primeiras atividades espontâneas, deliberadas, e sobretudo simbólicas. Elas eram verdadeiramente uma invenção sua, uma criação sua a partir de materiais externos, a fim de dominar as tensões internas" (Bettelheim, 1969, p.188). Esta atividade começou um dia após ela ter defecado. Por horas ela produziu, a partir de folhas de papel, longas fitas rasgando concentricamente a folha a partir de uma das bordas até atingir o centro. Ela aperfeiçoou o procedimento, começando por um recorte do centro, seguido de seu abandono acompanhado de uma expressão de desgosto ${ }^{8}$. Com a ajuda das fitas que fabricou, ele estava criando fronteiras entre seu mundo pessoal e o resto do mundo. A borda assim criada se fundamenta em uma perda dominada, que permite gerar um objeto protetor utilizado, não como carapaça, mas sim como fronteira. Ela não fecha um buraco, ela o delimita.

O procedimento utilizado por David, o menino carapaça de Tustin, é bastante similar. Trata-se de uma criança mais velha do que Laurie, ele tem quatorze anos, por isso a colocação em imagens é bem mais elaborada. A criação se estende a numerosas sessões, mas responde à mesma sequência que no caso anterior. $O$ fenômeno se origina na cessão de um objeto corporal, as fezes para Laurie, o pus de um abscesso para David. Para tratar desse buraco angustiante, a primeira opera a perda de um objeto "repulsivo", o segundo concretiza o objeto que sai, confeccionando "um monstro com olhos de morto". Nos dois casos, o fenômeno do corpo inicial, a cessão angustiante, se desloca em uma situação que permite dominar um buraco inquietante pela produção de um objeto protetor. Ao final, a menina produz uma fronteira protetora diretamente originada do buraco; enquanto o menino confecciona uma armadura para se proteger do "monstro no buraco" (Tustin, 1977, p.47). Apesar de suas reservas em relação ao objeto autístico, Tustin 
percebe que sua utilização é um "progresso" na cura (Tustin, 1977, p.168). Ora, quando examinamos a armadura de papelão, já que o autor nos forneceu imagens, percebe-se que não é uma carapaça compacta: ela é constituída de duas partes, um rosto e uma mão, não ligadas entre elas, enquanto que o rosto traz vestígios de buracos, pois comporta olhos, boca e orelhas. Tustin não se aprofunda na porosidade da armadura. Uma das funções iniciais da borda é certamente a de proteger o buraco, mas sem tapá-lo, o objetivo é de circunscrevê-lo. Ao delimitar o buraco real, a borda permite transmutá-lo em uma falta menos inquietante, com a qual o sujeito pode contemporizar.

Ao localizar seu gozo em um objeto externo, o sujeito autista mostra, como todo ser falante, que ele alimenta uma relação desordenada com o gozo de seu próprio corpo. Entretanto, por não dispor da função do significante unário, ele não a codifica em um índice do objeto perdido: ele se separa dela pela produção de um objeto concreto. Os fenômenos do corpo que precedem a construção da borda de Laurie e de David, defecação e extração de pus respectivamente, são deslocados e dominados pela construção e manipulação de um objeto externo. Nessas circunstâncias, o evento traumático não é codificado por um evento de corpo; o que conduz a ressaltar que a borda não é um sinthoma. Ele se fundamenta em uma primeira subtração de gozo que introduziu na economia do sujeito aquilo que Éric Laurent chamou de en-forma, não do objeto $a$, mas de um objeto de gozo que continua presente. A borda opera um corte no gozo, ele o coloca a distância e instaura uma ligação do sujeito ao objeto. É um operador de captura e tratamento do gozo, encarnado em um objeto concreto, em uma imagem, em uma pessoa, ou em um conjunto temático de signos. Se o psicótico tem o objeto no seu bolso, o autista conserva o objeto separado da mão, alocado em um en-forma.

Muitos interesses específicos parecem responder à mesma lógica do que a das primeiras bordas: sua fonte é um trauma em relação do qual desenvolveram um saber protetor. Uma criança autista que assistiu a morte do avô por uma parada cardíaca durante um passeio, não pareceu chorar a morte, mas desenvolveu um interesse pelas doenças cardíacas e leu todos os livros que pôde encontrar sobre doenças cardíacas.

Três elementos, muitas vezes intrincados, são constitutivos da borda: o objeto autístico, o duplo e o interesse específico. A máquina de Joey, que deveria fornecer-lhe a eletricidade que o anima, é ao mesmo tempo um objeto autístico, do qual ele não pode se separar, um duplo que é ao mesmo tempo uma máquina e a fonte de seu interesse específico, pois ele vai se tornar eletricista. Um ponto comum de maior relevância reside no excepcional investimento libidinal dedicado a cada um dos elementos. Todos são objetos de uma intensa paixão.

A crítica maior dos cognitivistas em relação à abordagem psicanalítica consiste em ressaltar que a criança autista se interessa muito pelo seu meio ambiente, mesmo que de forma lateral, de tal forma que o autista não poderia ser apreendido como resultando de um processo de retraimento social. A retenção de objetos pulsionais faz objeção a esta crítica. É pouco contestável 
que exista realmente uma fuga inicial das interações sociais; em compensação, é correto dizer que a criação da borda não está a serviço de um processo de encapsulamento. Os testemunhos das crianças autistas convergem no sentido de podermos afirmar que eles sofrem por sua solidão e que estão se esforçando para tentar retornar ao mundo.

\section{A borda como centro motor do gozo.}

O retorno do gozo sobre a borda, de acordo com a expressão de Éric Laurent, consiste em uma forma de desvio sobre este objeto de um gozo excessivo, que produz então uma animação do sujeito. Durante muitos anos, foi necessário que Joey fosse ligado em sua máquina-carro, na Escola Ortogênica de Chicago, para poder funcionar, graças à eletricidade que ela supostamente Ihe fornecia. Com a ajuda desta, ele era capaz de aparelhar o gozo pulsional: ela tornava possível a defecação ao aquecer as fezes, ela regulava a alimentação quando o acompanhava ao refeitório, ela trazia um alto-falante para tratar a voz e alimentava diversas lâmpadas elétricas que captavam o olhar. Ao se oferecer a ilusão de estar ligado em uma máquina, ou a um duplo, a criança autista aplaca seu sentimento de não estar viva, de não ter energia própria e se desincumbe de ter que tomar decisões. As emoções sentidas pelo autista, não sendo interpretadas pelo signo, são apreendidas como a ascensão de uma onda angustiante. Fazer-se de marionete de uma borda que capitaliza o gozo é uma maneira de tentar se livrar dele. Muitos explicaram que gostariam de ser máquina ou robô para não sentirem emoções.

Sem a cessão dos objetos pulsionais, a dinâmica desejante não se constrói, o que incita os observadores a descrevê-la como uma "doença da vontade" (Park, 1972, p.283). "O autismo", afirma Donna Williams, "havia precedido para ela o mínimo desejo pulsional. Minhas primeiras 'vontades', segundo ela, foram copiados de outros (frequentemente inspirado pela televisão)". Quando criança, ela se sentia "sem fundação, de forma que se assemelhava a um sujeito sob hipnose, totalmente aberta a uma programação ou uma reprogramação, sem questão nem identificação pessoal" (Williams, 1994, p.124).

Nos tratamentos individuais de autistas graves, quando o terapeuta consegue se fazer aceitar, a criança o coloca como centro motor de seu gozo, instaura com ele uma relação de fusão, de tal maneira que ele se transforma em um duplo dinâmico.

Peter, uma criança autista de uns dez anos, segundo sua terapeuta, "vivia todas as relações no abandono de sua identidade e na fusão com a outra pessoa" (Rothenberg, 1979, p.246).

No início [escreve Mira Rothenberg], eu era sua força, sua saúde, seu contato com a realidade, seu criador e salvador. [...] ele se colocou em um estado de profunda dependência em relação a mim [...] eu Ihe dava minha energia e lhe permitia depender de mim e se alimentar de minha força [...] Ele nunca se permitia assumir nenhuma 
responsabilidade na vida, como se só se interessasse pelo seu mundo imaginário. Quando eu Ihe pedia para escolher, ele me respondia: 'O que é que a Mira prefere?' [..] até mesmo no sofrimento ele recusava qualquer responsabilidade. Ele gritava, chorava, e era necessário ser um fino detetive para descobrir do que ele sofria. Ele nunca informava. Repetia frequentemente: A Mira tem que decidir pelo Peter. Isto faz bem para ele? Deixa ele mais à vontade (Rothenberg, 1979, p.277-279).

Esta vinheta clínica evidencia particularmente que o tratamento da falta é recolocado na borda, protegendo assim o sujeito de se arriscar a envolver seu desejo.

A ligação se torna mais discreta e menos permanente à medida em que a progressão no espectro do autismo em direção ao polo onde ele se torna muitas vezes socialmente invisível. Entretanto, uma autista sueca de auto nível como Gunilla Gerland relata ainda precisar se apoiar em uma borda para iniciar suas condutas.

Muito frequentemente [ela escreve], é mais fácil se eu tenho alguém comigo quando preciso fazer alguma coisa pela primeira vez, pois me permite de uma certa forma confiar no meu sistema nervoso: Para isso, eu praticamente me servi das pessoas. Fingi que demandava sua companhia quando na verdade eu precisava de uma escolta. Me fiz acompanhar por alguém para visitar um museu ou uma galeria onde eu nunca tinha ido antes, só para poder voltar mais tarde sem dificuldade. Às vezes, penso que eu gostaria, assim como um computador em rede, de poder me ligar ao sistema nervoso de outra pessoa para poder me servir dele em tais circunstâncias, ao invés de precisar levá-la comigo e ter de encontrá-la e agir ao mesmo tempo (Gerland, 2004. P.232).

A necessidade para Temple Grandin de utilizar seu dispositivo de compressão era intermitente. Bastava para ela colocar-se nele por um certo tempo para obter uma regulação de seu gozo. A construção desta borda complexa merece um pouco de atenção, pois retrata muito bem o encapsulamento autístico concebido por Tustin. Em uma primeira análise, a permanência no dispositivo, cujas paredes devem comprimi-la estreitamente, pareceria permitir a operação de um retorno ao gozo fusional compartilhado que caracteriza a ligação com as bordas iniciais. Ela relata que esta máquina se originou da ideia de "um tipo de caixa que se parece com um caixão" (Grandin, 1994, p.51), ela extrai o modelo dos equipamentos pecuários dos quais ela se tornou uma especialista mundial, nas suas próprias palavras, "uma das máquinas de matar mais eficientes do mundo" (Grandin, 1997, p.238). Grandin não esconde que ela se aloja no dispositivo assim como uma vaca e que este animal é como um duplo para ela. Entretanto, quando o animal sai dele é para ir para a morte. Grandin não está longe de conceber que o dispositivo tenha a função de tratar o trauma da morte pelas saídas reiteradas de sua proteção. 
A maior parte das pessoas não se dá conta que a morte nos abatedouros é muito mais delicada do que a morte natural. Os animais selvagens morrem de fome, ou são vítimas de predadores, ou degradam-se por causa do clima. Se eu tivesse escolha preferiria passar por um sistema de abate industrial do que ter minhas tripas arrancadas ainda viva pelos coiotes ou leões (Grandin, 1997, p.238).

Uma das características do autista de alto nível é a de ter atingido um esvaziamento do gozo excessivo da borda. Os cortes reiterados por Grandin na fusão restaurada com a borda parecem ter contribuído para o resultado. É só muito mais tarde, em 2010, que ela menciona que sua máquina quebrou e ela não a consertou. Subsistem apesar de tudo, dois interesses específicos que medeiam suas relações sociais: um deles é por meio dos corredores para gado e o outro pelo saber sobre o autismo.

\section{O esvaziamento da borda}

O esvaziamento da borda acontece quando o autista toma a decisão de operar uma perda em relação a ele. Sua propensão a recorrer às imagens permite, às vezes, que ele o encene. $\mathrm{A}$ cessão do gozo ainda pode advir quando o sujeito assume o risco de se desfazer, temporariamente, de seu sistema de proteção em relação às trocas sociais; o que equivale a um desinvestimento parcial da função da borda.

Williams sofreu por muito tempo com a presença de seus companheiros imaginários, que Ihe permitiam de fato uma adaptação social, mas que faziam persistir uma certa vivência de "mutilação psíquica" quando ela se ligava a eles. Por isso, ela compreendeu que "sua evolução deveria passar pelo desaparecimento da 'parte dela mesma' que eles representavam". Na adolescência, ela tentou se separar de Willie. Nas palavras da autora:

"decidi matar Willie, este outro eu sempre zangado. Tinham me dado um boneco de menino, vestido de calça jeans e camisa. Eu o enrolei em um pedaço de tecido vermelho escocês, um tecido que minha avó adorava. [...] consegui uma caixinha de papelão e pintei de preto. Esperei que não houvesse... Esperei que não houvesse mais ninguém em casa e, em seguida, fui ao lago dos peixes onde submergi minha personificação simbólica de Willie no seu caixão negro, apagando minuciosamente qualquer vestígio de um funeral (Willians, 1992, p.113).

Carol e Willie, dois elementos da borda de Williams, forneciam-lhe uma "proteção anestesiante" (Willians, 1994, p.159) que lhe permitiria "suprimir" a emoção (Willians, 1992, p.143). O homicídio imaginário de Willie não foi realizado imediatamente: foram necessários ainda longos anos antes que assuma seu desaparecimento, mas ele revela como um autista de alto nível 
consegue tratar sua borda: por meio de um esvaziamento progressivo do que a constitui, através do qual se atenua o gozo que lhe está aderido.

Williams sublinha a importância que tomou para ela a cessão de uma de suas bordas, seu primeiro livro, aceitando separar-se dela por meio da publicação. A notícia da aceitação de seu manuscrito a mergulhou em uma viva inquietude.

As vidas de Carol, Willie e a minha iam ser expostas pelo mundo. Eu era a mais evasiva das pessoas que eu conhecia e iria me tornar uma das mais públicas. [...] era difícil acreditar que se tratava do 'meu' livro. Eu perdia todo o controle; outros iam ler minhas palavras. Senti vontade de encontrar cada exemplar, rasgá-los e queimar-lhes os pedaços (Willians, 1992, p.124).

Também foi decisiva para ela a descoberta tardia "de que para pensar e sentir; uma coisa precisaria dispor de um sistema nervoso"" (Willians, 1992, p.100). Foi muito difícil para ela a aceitação da ideia de que os objetos são mortos, "sem conhecimentos, sem sentimentos, sem volição". Esse esvaziamento do gozo da borda, que ela associa ao desaparecimento de seus companheiros imaginários, deu-lhe o sentimento de ser abandonada pelas coisas que the deram segurança. Ela continuou, entretanto, mantendo alguns objetos à distância desta nova lógica material, particularmente dos animais de pelúcia batizados de "urso Orsi" e "Cão Viajante". Eles Ihe serviam para estabelecer "pontes com o mundo exterior" (Willians, 1992, p.100). Um indício de que o esvaziamento da borda é um trabalho progressivo que se opera por uma reiteração das cessões do gozo.

Este processo pode se inserir no tratamento de uma criança autista e nele introduzir escansões decisivas. Dibs produz disso uma representação quando termina sua psicoterapia por uma captura de sua voz e uma encenação de sua perda. "Escute-me bem gravador", ele declara. "Você vai capturar e guardar minha voz. [...] eu vou fazer uma longa gravação e nós a guardaremos para sempre e para sempre. Vai ser certo para nós dois" (Axline, 1967, p.197). Ao final, ele insiste no fato de que sua psicoterapeuta precisa guardar a gravação: "Guarde esta fita, coloque-a na caixa e guarde-a só para nós dois" (Axline, 1967, p.199). Esta assunção de uma cessão de gozo se acompanha de uma colocação em jogo da dimensão da falta em sua relação com o Outro. Ele sabe que as férias de verão vão interromper sua psicoterapia que está chegando ao fim. Ele diz à terapeuta: "-vou sentir sua falta. Vou sentir falta de vir aqui". Acrescenta: "- Vai sentir falta de mim?" (Axline, 1967, p.210). Alguma coisa agora pode faltar ao sujeito, assim como falta ao Outro e, entretanto, não está perdida, mas captada por um veículo que permanece acessível. Dois anos e meio após o final do tratamento, quando sua terapeuta o reencontra, ela constata que ele desenvolveu um interesse específico no domínio da botânica, derivado da árvore que foi um de seus objetos autísticos. 
A evolução do trabalho de Joey, a criança-máquina da Escola Ortogênica de Chicago, mostra uma sucessão de elaborações da borda, que passa das máquinas assustadoras a formas cada vez mais humanas e amistosas. Kenrad, que tende a trocar a máquina pelo tratamento do gozo anal, é ainda todo-poderoso e perigoso, pois sua defecação ainda é um evento cósmico inquietante. Mitchell, ao qual Joey se apega em seguida, é um menino protetor ao seu lado, permitindo que sua defecação não produza mais explosões e luzes. Valvus, o companheiro imaginário que lhes sucede, era capaz de se autorregular, podendo se abrir e se fechar como uma válvula, quando necessário. Com ele, Joey atingiu um controle da sua própria eliminação, que tanto o angustiava. Aparece claramente que o processo de eliminação das encarnações da borda se faz por esvaziamentos reiterados do gozo excessivo atribuído a este. Ao final, parece que ao apagar os duplos, Joey conseguiu reduzir sua borda ao interesse específico que representavam para ele as máquinas elétricas, já que pode fazer de lidar com elas sua profissão.

O privilégio do signo no pensamento dos autistas induz o desenvolvimento de capacidades mnemônicas extraordinárias. Alguns transformam seus talentos neste domínio em um interesse específico, do qual procuram tirar alguns proveitos e relações sociais. Em meio a suas diversas profissões "provisórias", Vienamin Cherechevsky tentou fazer carreira como mnemonista, encenando um espetáculo. Eventualmente Ihe ocorria ficar incomodado por sua memorização sem limites. Sem conseguir apagar os dados que lhe haviam sido submetidos durante suas sessões, que seguiam um ritmo muito intenso, ele teve medo de que eles se superpusessem e o conduzissem a cometer erros. Ele fez então a experiência de escrever em pedaços de papel o que precisava esquecer e depois queimá-los. Infelizmente esta perda concreta colocada em imagens não funcionou. Ele conta que

[...] naquela noite, eu já havia feito três espetáculos e me perguntava como sustentar uma quarta performance, já esperava ver aparecer os números das três sessões anteriores... Estava angustiado... Veria eu, em um instante, aparecer o primeiro quadro? Veria eu, logo o primeiro quadro? Estava apreensivo. Dizia a mim mesmo: eu quero - eu não quero...e o quadro não aparecia. O motivo disso é compreensível: é por que eu não quero! Ah! Desta forma se eu quiser ele não aparecerá...então é só tomar consciência disso! (Luria, 1970, p.61).

Surpreendentemente, comentou Luria, isso funcionou. Se admitirmos que se trata de uma decisão tomada de se separar de sua borda, introduzindo nela uma falta apaziguadora, o fenômeno parece menos surpreendente. A modificação da posição subjetiva de Vieniamin que acompanha este descolamento salvador parece confirmá-lo:

eu me senti liberado de uma só vez, constata ele, a certeza ser incapaz de errar me deu 
confiança. Eu falo com mais conforto, posso me permitir o luxo de fazer pausas, sei que eu posso impedir a aparição das imagens quando eu quero. Eu me sinto perfeitamente bem" (Luria, 1970, p.61).

Ele conseguira tomar para si uma parte do gozo que atribuía à sua borda. O esvaziamento da borda permite aos autistas de alto nível remediar o problema inicial da comunicação, que se origina na retenção dos objetos pulsionais. Grandin o expressa claramente:

[...] alguma coisa aconteceu durante o processo que desconectou o 'fio' no cérebro que liga uma criança à sua mãe e aos outros seres humanos que the oferecem seu afeto. Foi só quando me tornei adulta e experiente o suficiente para construir a máquina de apertar, que a conexão foi reparada" (Grandin, 1986, p.128).

Se a ancoragem no Outro for restaurada, parece, entretanto, que ele deva continuar sendo intermediado por uma borda, mas reduzida ao interesse específico. "A invenção é o único 'remédio' do sujeito autista, ressalta Éric Laurent, e ela deve, a cada vez incluir o 'resto' ou seja, o que resta no limite da sua relação com o Outro: seus objetos autísticos, suas estereotipias, seus duplos" (Laurent, 2012, p.65).

Muitas vezes é difícil estabelecer um tratamento com uma criança autista. A transferência inicialmente é bloqueada. Quando o analista consegue se fazer aceitar, através de uma atitude não intrusiva, associada a condutas em espelho ou em paralelo, uma transferência fusional se instaura, o analista se torna um duplo. O esvaziamento da borda conduz em seguida a um descolamento do duplo e a um investimento temperado de um interesse específico.

As angústias ligadas a cessão dos objetos pulsionais incitam os autistas a uma apropriação solitária da linguagem, que os leva a supervalorizar neste processo as percepções visuais e tácteis, a privilegiar o signo e gerar uma borda que é uma formatação do objeto de gozo. Os métodos de aprendizado oferecidos para aplicação em autistas encontram um limite quando omitem que, para que sua construção subjetiva se sustente, ela precisa ter um ponto de apoio na borda. Mas não basta aceitar a implantação deste ponto de apoio. Também é necessário acompanhar um trabalho de esvaziamento do gozo excessivo, respeitando o interesse específico.

As abordagens cognitivistas não consideram que a evolução da borda se produza por saltos criativos gerados por uma perda, e que as angústias iniciais do autista se originam da retenção dos objetos pulsionais. Nem mesmo as mais pertinentes, que incitam a se apoiar nos 'pontos fortes' para o tratamento conhecem essas duas construções, por isso, mesmo desagradando aos especialistas, a abordagem psicanalista permanece inevitável para orientar o trabalho com autistas.

Tradução: Catarina Coelho dos Santos. 
Revisão técnica: Tania Coelho dos Santos.

\section{Notas}

1. A intervenção de Jean-Claude Maleval aconteceu em Lyon, na terça feira, dia 13 de março de 2018, no âmbito da I'ACF-RA. Publicamos aqui a integralidade da conferência. Ela foi revista e parcialmente modificada pelo autor.

2. Agradeço a V. Gay por ter me entregue um documento não publicado na língua particular de Théo.

3. $1 / \mathrm{Aa} ; 2 / \mathrm{Na} ; 3 / \mathrm{Ya} ; 4 / \mathrm{Ka} ; 5 / \mathrm{Yaa} ; 6 / \mathrm{Si} ; 7 / \mathrm{Sa} ; 8 /$ oui ; 9/Io ; $10 / \mathrm{Di} ; 11 / \mathrm{On} ; 12 /$ dou ; $13 /$ Ttai (soufflé) ; 14/To ; 15/Tin ; 16/Té ; 17/di-sa ; 18/di-oui ; 19/Dio ; 20/va.

4. "Os números são minha língua materna, aquela em que eu penso e sinto" (Tammet, 2007, p.15).

5. "Minhas lembranças sempre se apresentam em ordem cronológica, e as imagens são sempre particulares" (Grandin, 1997, p.29].

6. "O inconsciente precisa lidar de início com a gramática, existe também a necessidade de lidar um pouco, muito, inteiramente, com a repetição, isto é, o caminho contrário à utilidade de um dicionário" (Lacan, 04/11/1971).

7. Aqui ela utilizou o "Tu" no lugar do "je" como fazia frequentemente.

8. "No último estágio desta evolução [observa Bettelheim], ela rasgava o centro da folha de papel desde o início, o jogava fora, ainda com uma expressão de repulsa, e em seguida rasgava a folha concentricamente, dirigindo-se ao centro, agora vazio. Era impressionante constatar com que destreza ela removia, aparentemente sem esforço, o centro exato da folha de papel e chegava exatamente ao mesmo lugar quando acabava de rasgar" (Bettelheim, 1969, p.187).

Tradução: Catarina Coelho dos Santos. Revisão técnica: Tania Coelho dos Santos.

\section{Referências bibliográficas}

Axline, V. (1967). Dibs. Développement de la personnalité grâce à la thérapie par le jeu (1964).

Paris: Flammarion.

Berquez, G. (1983). L'autisme infantile. Paris: PUF.

Bettelheim, B. (1969). La forteresse vide. Paris: Gallimard.

Blake, J., Boysson-Bardies, B. (1992). Patterns in babbling: a cross-linguistic study, Journal of Child Language, 19(1), 1992, pp.51-74.

Boysson-Bardies, B. (1996). Comment la parole vient aux enfants. Paris: O. Jacob.

Chericoni N., De Brito, Wanderley D., Constanzo V., Diniz-Gonçalves, A., Leitgel, Gille M., Parlato, 
E., Cohen, D., Apicella, F., Calderoni, S., Muratori, F. (2016) Pre-linguistic Vocal Trajectories at 6-18 months of Age As Early Markers of Autism. Front. Psycholog. $7: 1595$. Doic 10.3389/fpsyg. 2016. 01595.

Damaggio, N. (2011). Une épée dans la brume. Syndrome d'Asperger et espoir. Paris: Anne Carrière.

Danon-Boileau, L. (2002). Des enfants sans langage. Paris: O. Jacob.

Dechais, A. (2009). Libres propos philosophiques d'une autiste. Paris: Presses De La Renaissance.

De Clerq, H. (2005). Dis maman, c'est un homme ou un animal?. Paris : AFD.

Dovan, J., Zucker, C. (2010, out). "Autism's First Child. Atlantic Magazine". October 2010. http://www.theatlantic.com/magazine/archive/2010/10/autism-8217-s-first-child/8227/

Donville, B. (2006). Vaincre l'autisme. Paris: O. Jacob.

Gay-Corajoud, V. (2018). Nos mondes entremêlés, Imprim'vert.

Gerland, G. (2004). Une personne à part entière. AFD, Mougins.

Grandin, T. (1994). Ma vie d'autiste (1986). Paris: Odile Jacob.

Grandin, T. (1997). Penser en images (1995). Paris: Odile Jacob.

Harrisson, B. (2010). L'autisme au-delà des apparences. Concept ConsulTED, Rivière du loup, Québec, Canada.

Hebert, F. (2006). Rencontrer l'autiste et le psychotique. Paris: Vuibert.

Higashida, N. (2014). Sais-tu pourquoi je saute? Paris: Les Arènes.

Hody, F. (2008). Pertinence clinique de la distinction de l'autisme. Les Feuillets du Courtil.

Jackson, L. (2007). Excentriques, Phénomènes et Syndrome d'Asperger. Paris: AFD Editions, Mouans Sartoux.

Kanner, L. (2002). "Le langage hors-propos et métaphorique dans l'autisme infantile précoce" (1946), American Journal of Psychiatry, 1946,103, p.242. Tradução de G. Druel et F. Sauvagnat, in Psychologie clinique, 2002, 14, pp. 204-213.

Kanner, L. (1983). "Troubles autistiques du contact affectif". In BERQUEZ G., L'autisme infantile, Paris: PUF.

Kantzas P. (1987). Le passe-temps d'un Dieu. Analyse de l'autisme infantile. Paris: Dialogues.

Lacan, J. (1966). "Cénac M. Introduction théorique aux fonction de la psychanalyse en criminologie" (1950). In Écrits 1. Paris : Seuil.

Lacan, J. (1966). "Remarque sur le rapport de Daniel Lagache". In Écrits. Paris: Seuil.

Lacan, J. (1971). "Le savoir du psychanalyste". Conferência inédita proferida no hospital Saint Anne em 4 de novembro de 1971.

Lacan, J. (1950 [1966]). "Cénac M. Introduction théorique aux fonction de la psychanalyse en criminologie". In Ecrits 1. Paris: Seuil.

Lacan, J. (2001). "L'étourdit" (1973), Autres écrits. Paris: Seuil.

Lacan, J. (1974). Les non-dupes errent. Le Séminaire. Livre XXI, inédit du 11 Juin 1974. 
Lacan, J. (1975a). Le Séminaire. Livre I, Les écrits techniques de Freud (Trabalho original publicado em 1953-1954). Paris : Seuil.

Lacan, J. (1975b). Le Séminaire. Livre XX, Encore (Trabalho original publicado em 1972-1973). Paris: Seuil.

Lacan, J. (1985). Conférence de Genève sur "Le symptôme" du 4 Octobre 1975. Bloc-note de la psychanalyse.

Laurent, É. (1992). Discussion, in L'autisme et la psychanalyse. Presses Universitaires du Mirail.

Laurent, É. (2012). La bataille de l'autisme (De la clinique à la politique). Paris : Navarin.

Lefort, R.; Lefort, R. (1980). Naissance de l'Autre. Paris: Seuil.

Lefort, R.; Lefort, R. (1998). L'autisme, spécificité. In Fondation du champ freudien. Le symptômecharlatan. Paris: Seuil.

Lefort, R.; Lefort, R. (2003). La distinction de l'autisme. Paris: Seuil.

Lemay M. (2004). L'autisme aujourd'hui. Paris: Odile Jacob.

Luria, A.R. (1970). Une prodigieuse mémoire, Étude psycho-biographique. Delachaux et Niestlé, Neuchâtel.

Miller, J-A. (1975). "Théorie de lalangue", Ornicar?, Bulletin périodique du champ freudien.

Miller, J-A. (2005). "Pièces détachées", La Cause Freudienne, nº61.

Mottron, L. (2004). Une outre intelligence. Editons Mardaga.

Mottron, L. (2016). L'intervention précoce pour enfants autistes. Paris : Mardaga.

Nazeer, K. (2006). Laissez entrer les idiots. Paris : Oh Editions.

Ouellette, A. (2011). Musique autiste. Paris :Triptyque.

Park, C. (1972). Histoire d'Elly (1967). Calmann-Lévy, Paris.

Peeters, T. (1996). L'autisme. De la compréhension à l'intervention. Paris : Dunod.

Richer, J. (1978). "L'absence partielle de transmission culturelle chez l'enfant autiste". In Rutter M., Schopler, E. (1991). L'autisme. Une réévaluation des concepts et du traitement, Paris: PUF.

Rothenberg, M. (1977/1979). Des enfants au regard de pierre). Paris: Seuil.

Saussure, F. (1972). Cours de linguistique générale. Paris: Payot.

Sellin, B. (1994). Une âme prisonnière (1993). Paris: Robert Laffont.

Sellin, B. (1998). La solitude du déserteur (1995). Paris: Robert Laffont.

Tammet, D. (2007). Je suis né un jour bleu (2006). Paris: Les Arènes.

Tammet, D. (2018). Conférence à I'Université Rennes 2; du 28 Mars 2018.

Tustin, F. (1977). Autisme et psychose de l'enfant (1972). Paris: Seuil.

Tustin, F. (1992). Autisme et protection (1990). Paris: Seuil.

Williams, D. (1992). Si on me touche, je n'existe plus. Paris: Robert Laffont.

Williams, D. (1994). Quelqu'un, quelque part. Paris : J'AI LU. 
Citacão/Citation: Maleval, J.C. (mai. 2018 a out. 2018). Da estrutura autista. Revista aSEPHallus de Orientação Lacaniana, 13(26), 4-38. Disponível em www.isepol.com/asephallus. Doi: 10.17852/1809709x.2019v13n26p4-38.

Editor do artigo: Tania Coelho dos Santos.

Recebido/Received: 03/01/2019 / 01/03/2019.

Aceito/Accepted: 12/03/2019 / 03/12/2019.

Copyright: (C) 2019 Associação Núcleo Sephora de Pesquisa sobre o moderno e o contemporâneo. Este é um artigo de livre acesso, que permite uso irrestrito, distribuição e reprodução em qualquer meio, desde que o autor e a fonte sejam citados/This is an open-access article, which permites unrestricted use, distribution, and reproduction in any medium, provided the author and source are credited. 